Article

\title{
Chronic HCV Infection Is Associated with Overexpression of Human Endogenous Retroviruses that Persists after Drug-Induced Viral Clearance
}

\author{
Pier-Angelo Tovo ${ }^{1, *}$, Silvia Garazzino ${ }^{2}\left(\right.$ ) , Valentina Daprà ${ }^{3}$, Carla Alliaudi ${ }^{1,3}$, Erika Silvestro ${ }^{2}$, \\ Cristina Calvi ${ }^{1,3}$, Paola Montanari ${ }^{1,3}$, Ilaria Galliano ${ }^{1,3}$ and Massimiliano Bergallo ${ }^{1,3, *}$ \\ 1 Department of Pediatric Sciences and Public Health, University of Turin, Piazza Polonia 94, 10126 Turin, \\ Italy; carla.alliaudi@unito.it (C.A.); cristina.calvi@unito.it (C.C.); paola.montanari@unito.it (P.M.); \\ ilaria.galliano@unito.it (I.G.) \\ 2 Department of Pediatrics, Infectious Diseases Unit, Regina Margherita Children's Hospital, Piazza Polonia \\ 94, 10126 Turin, Italy; silvia.garazzino@unito.it (S.G.); erika.silvestro@unito.it (E.S.) \\ 3 Pediatric Laboratory, Department of Pediatric Sciences and Public Health, University of Turin, 10126 Turin, \\ Italy; valentina.dapr@yahoo.it \\ * Correspondence: pierangelo.tovo@unito.it (P.-A.T.); massimiliano.bergallo@unito.it (M.B.)
}

Received: 17 February 2020; Accepted: 28 May 2020; Published: 1 June 2020

check for updates

\begin{abstract}
Chronic hepatitis $\mathrm{C}$ virus (HCV) infection is associated with several hepatic and extrahepatic complications, including cancers and autoimmune disorders, whose frequency is reduced but not abolished after drug-induced viral clearance. The causes of these complications and of their persistence are ill-defined. Human endogenous retroviruses (HERVs) are remnants of ancestral infections and constitute $8 \%$ of the human genome. Most HERV elements are inactive, but some are transcribed. HERV overexpression is associated with many cancers and autoimmune diseases with a putative pathogenetic role. Several viral infections trigger HERV activation, but there are no studies on HCV-infected subjects. We assessed, through a PCR real-time amplification assay, the transcription levels of the pol genes of HERV-H, $-\mathrm{K}$, and -W, and of their repressor TRIM28 in white blood cells (WBCs) of vertically infected children, both before and after therapy with direct-acting antivirals (DAAs). The results documented significantly higher expressions of HERV-H-pol and HERV-K-pol, not of HERV-W-pol, in HCV-infected subjects as compared to age-matched controls. HERV RNA levels remained unchanged after DAA-driven viral clearance. No significant variations in transcription levels of TRIM28 were observed in infected subjects. Our findings demonstrate HERV-H-pol and HERV-K-pol overexpression in subjects with chronic HCV infection, without variations after a positive response to DAAs; this might justify their predisposition to cancers and autoimmune disorders that persist after a DAA-induced resolution of viremia.
\end{abstract}

Keywords: hepatitis $C$ virus infection; human endogenous retroviruses; viral clearance; cancers; autoimmune diseases

\section{Introduction}

Chronic hepatitis $\mathrm{C}$ virus (HCV) infection is associated with a large array of hepatic and extrahepatic complications [1]. These include a number of malignancies, such as hepatocellular carcinoma (HCC), B cell lymphoma [2], and other solid tumors [3,4], as well as autoimmune manifestations, such as cryoglobulins, membranoproliferative glomerulonephritis, and thyroid diseases [5]. Eradication of infection, either with interferon alfa or with direct-acting antivirals (DAAs), has reduced but not abolished the predisposition to cancers [6,7]. Even the risk of autoimmune disorders does not disappear after the resolution of viremia. In our cohort of vertically $\mathrm{HCV}$-infected children, cryoglobulins 
and non-organ-specific autoantibodies persisted or developed in subjects with spontaneous viral clearance $[8,9]$. Meanwhile, it became clear that the persistence or appearance of autoantibodies and cryoglobulins, as well as relapses of vascular disorders, may occur in a significant proportion of adults with a positive response to direct-acting antivirals (DAAs) $[10,11]$. The cause of the predisposition to cancers and autoimmune diseases in HCV-infected subjects, and of its persistence after spontaneous or drug-induced viral clearance, remains an unsolved dilemma.

Human endogenous retroviruses (HERVs) constitute about $8 \%$ of the human genome. They are the remnants of ancestral infections that led to their integration into the DNA of primates, more than 25 million years ago [12]. During evolution, the accumulation of mutations, deletions, and recombinations blocked the production of infectious virions. Most HERV elements have become inactive through progressive mutations or epigenetic silencing. However, some are transcribed, and a few encode viral proteins, such as the syncytins that are involved in placenta morphogenesis and in feto-maternal tolerance, but postnatally may favor cancer development and diffusion $[13,14]$. HERVs can regulate the transcription of adjacent cellular genes and generate novel insertions into the genome by retrotransposition of their pseudogenes [12]. Aberrant HERV expressions have been found in association with a number of cancers $[15,16]$ and autoimmune disorders $[17,18]$ supporting their putative pathogenetic role in these pathologies. Among epigenetic factors that can regulate HERV expression, the host factor tripartite motif-containing-28 (TRIM28, also known as KAP1 or TIF1 $\beta$ ) is a transcriptional corepressor acting in concert with Krüppel-associated box domain-zinc finger proteins (KRAB-ZNFs) to induce DNA methylation and silencing of endogenous retroviral elements $[19,20]$.

Several exogenous viral infections can trigger HERV activation [21-24] and, recently, wild-type influenza A virus has been shown to induce alterations of TRIM28 that reduce the repression of endogenous retroviruses [25]. HERV activation has not been explored in chronic HCV infection, either before or after the resolution of viremia. Several groups of HERVs have been identified; among these, HERV-H, HERV-K, and HERV-W are those most widely studied. The aims of this study were to assess the transcription levels of the pol genes of HERV-H, $-\mathrm{K}$, and $-\mathrm{W}$ in white blood cells (WBCs) of HCV RNA+ children and adolescents with vertically acquired infection, their variations following DAA-induced viral clearance, and to determine whether abnormal HERV transcriptions were associated with alterations of their repressor TRIM28.

\section{Results}

\subsection{Study Populations}

Seventeen HCV RNA+ subjects were studied (6 males, 11 females; median age 12.49 years, range 1.23-17.37). Their viral genotypes were type 1 in 14 cases, type 2 in 1 case, and type 4 in 2 cases. General condition was good in all patients, and none had other pathologies, including autoimmune diseases. Four had mild biochemical signs of hepatitis (ALT mean values +/- SD: $83 \mathrm{U} / \mathrm{mL}+/-31.4$ ); four had cryoglobulinemia, one patient had ANA, and one had anti-LKM-1 antibodies. No cases of cirrhosis were detected.

The control population included 37 age-matched control subjects ( 24 males, 13 females; median age 12.39 years, range $2.05-16.60)$.

\subsection{Expression Levels of Housekeeping Gene GAPDH}

Expression of housekeeping gene GAPDH was similar between HCV-infected subjects and age-matched controls (mean +/- SD: $21.83+/-0.38$ ct vs. $21.81+/-0.73 \mathrm{ct}$, respectively, $p=0.6474$ ). 
2.3. Transcription Levels of HERV-H-pol, HERV-K-pol, and HERV-W-pol in HCV RNA+ Subjects and Control Group

The transcription levels of the pol genes of HERV-H and HERV-K were significantly higher in HCV-infected patients than in the age-matched control subjects, whereas those of HERV-W did not show a significant difference (Figure 1).

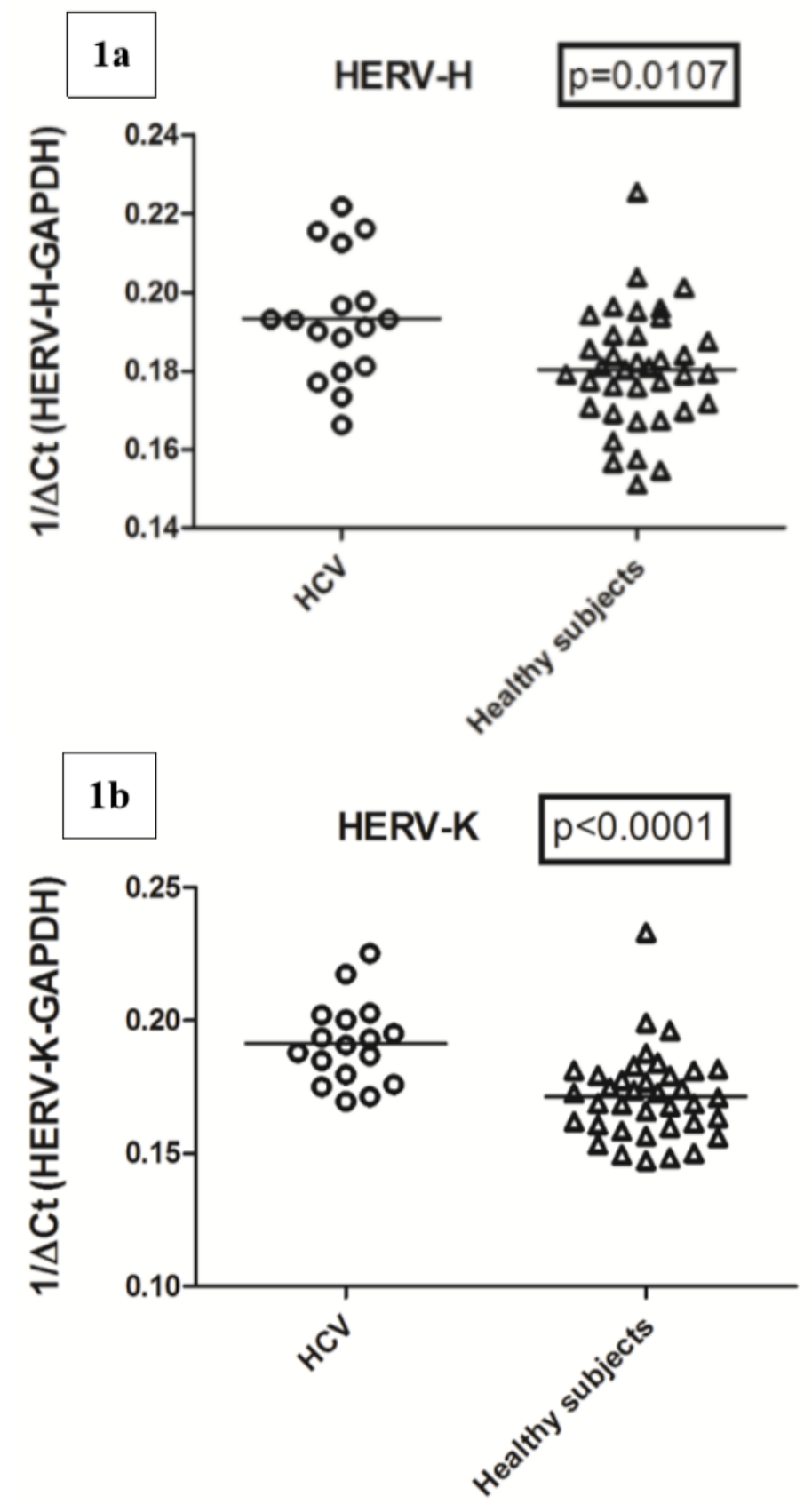

Figure 1. Cont. 


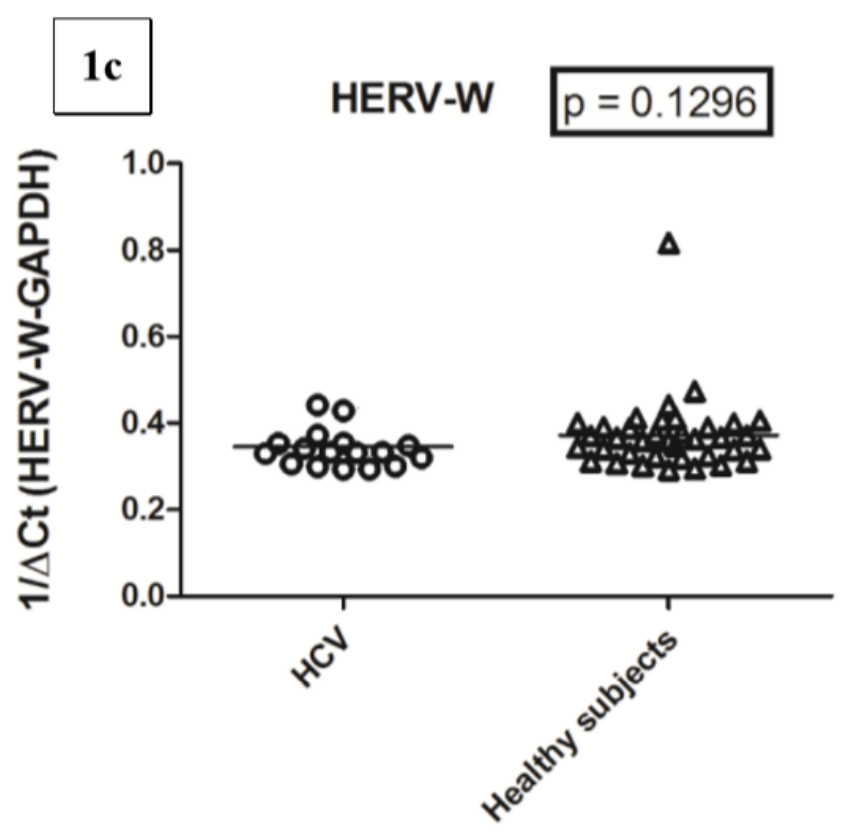

Figure 1. Transcriptional levels of the pol genes of human endogenous retroviruses (HERVs), HERV-H (a), HERV-K (b), and HERV-W (c) in white blood cells (WBCs) from hepatitis C virus (HCV) vertically infected subjects and age-matched control subjects. Circles and triangles show transcriptional levels of each subject; these are represented by $1 / \Delta \mathrm{Ct}$. Statistical analysis through the Mann-Whitney test.

In particular, the HERV-H-pol values (mean +/- SD) were $0.192+/-0.015$ in HCV+ subjects vs. $0.180+/-0.015$ in control subjects; the HERV-K-pol values were $0.190+/-0.016$ in HCV+ vs. $0.171+/-$ 0.017 in control subjects. The transcription levels of HERV-W-pol values were $0.346+/-0.049$ in HCV+ vs. $0.372+/-0.086$ in controls.

\subsection{Transcription Levels of HERV-H-pol, HERV-K-pol, and HERV-W-pol Following Therapy with DAAs}

All the eight HCV-infected subjects (median age 13.10 years, range 12.42-17.07; 5 males, 3 females; 6 genotype 1, 2 genotype 4) who were treated with sofosbuvir/ledipasvir had a resolution of viremia at the end of therapy that persisted 3 months later.

Transcription levels of every HERV-pol gene did not change significantly before (time 0), after 1 month (time $1 ; 6 / 8$ subjects tested) and at suspension (time 3 ) of sofosbuvir/ledipasvir therapy, and 3 months later (time 6;6/8 subjects tested) (Figure 2).

In particular, the HERV-H-pol values (mean +/- SD) were $0.189+/-0.015$ at time $0 ; 0.203+/-$ 0.025 at time $1 ; 0.219+/-0.033$ at time 3; $0.192+/-0.026$ at time 6 ; HERV-K-pol values were: 0.190 $+/-0.017$ at time $0 ; 0.193+/-0.011$ at time $1 ; 0.207+/-0.030$ at time 3 ; and $0.181+/-0.025$ at time 6; and HERV-W-pol values were $0.326+/-0.027$ at time $0 ; 0.363+/-0.055$ at time $1 ; 0.437+/-0.155$ at time 3; and $0.342+/-0.040$ at time 6 .

\subsection{Expression Levels of TRIM28 in HCV RNA+ Subjects and Control Group}

Expression levels of TRIM28 did not differ significantly between HCV RNA+ subjects and the control group (mean +/- SD: $0.289+/-0.035$ vs. $0.263+/-0.036$, respectively (Figure 3). 

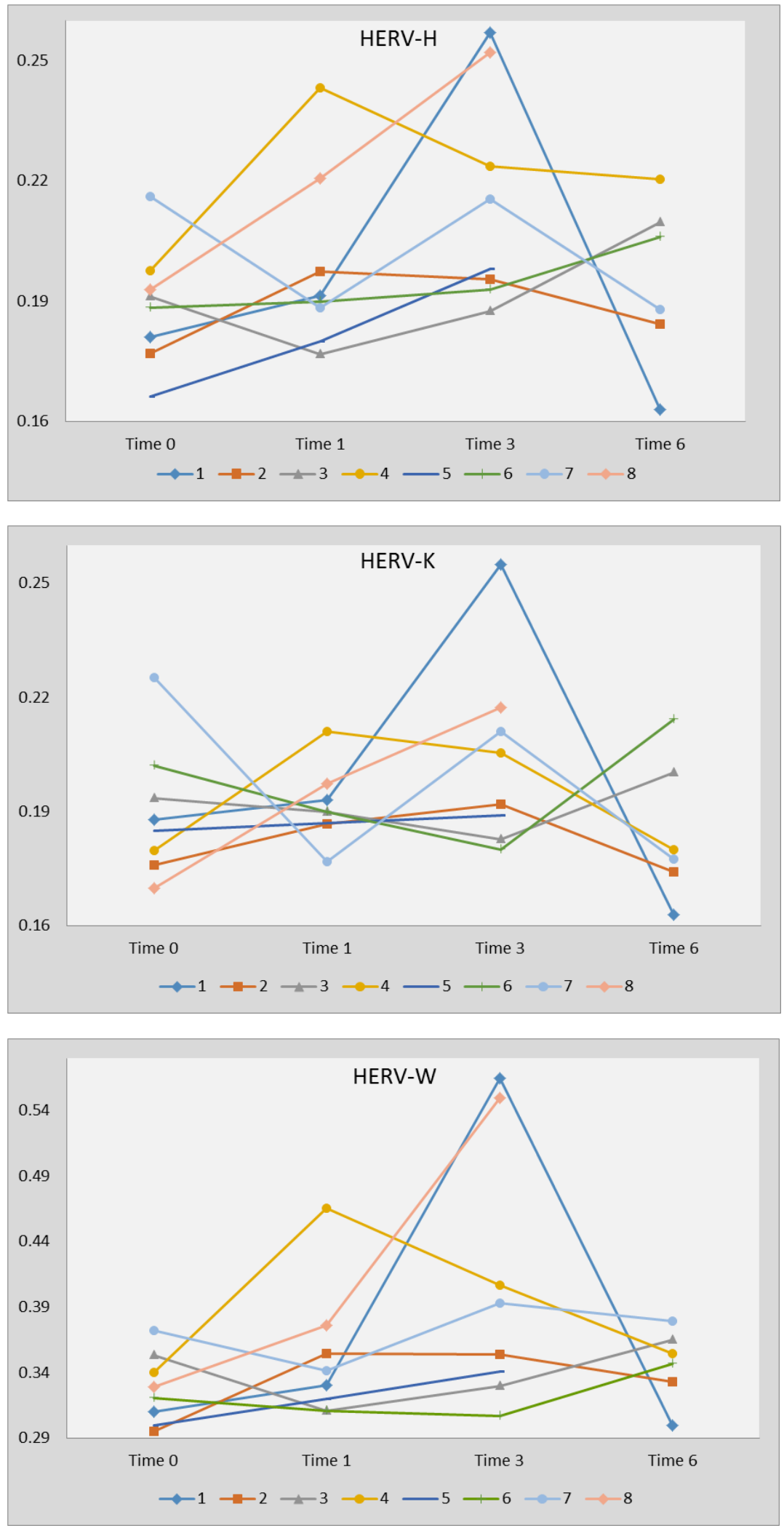

Figure 2. Transcription levels of the pol genes of HERV-H, HERV-K, and HERV-W in WBCs from HCV-infected subjects before (time 0), after 1 month (time 1) and at suspension (time 3) of sofosbuvir/ledipasvir therapy, and 3 months later. Transcription levels are represented by $1 / \Delta \mathrm{Ct}$. Statistical analysis through two-way ANOVA test: HERV-H $p=0.1886$, HERV-K $p=0.2884$, and HERV-W $p=0.1619$. Patients $1,3,4,5,7,8$ were infected with genotype 1 ; patients 2 and 6 were infected with genotype 4 . 


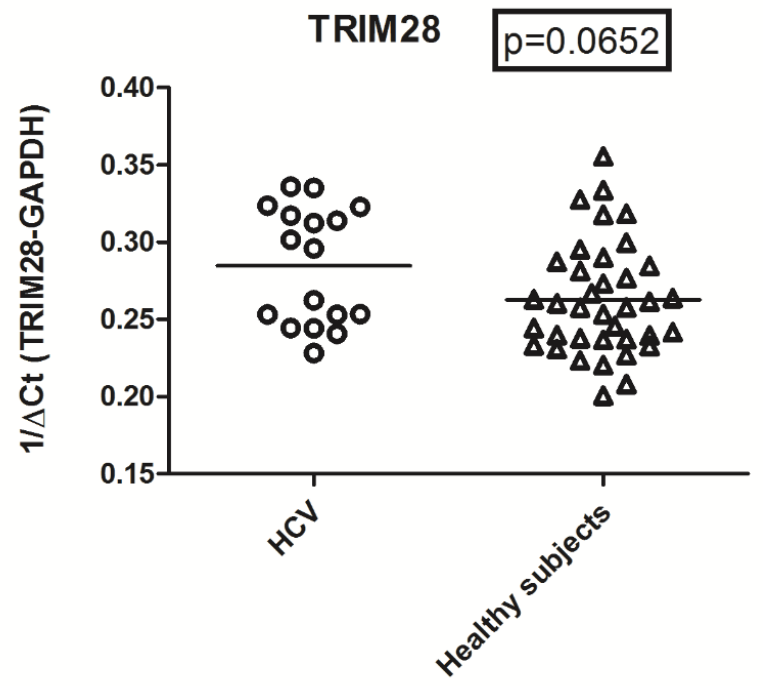

Figure 3. Transcription levels of TRIM28 in WBCs from HCV-infected subjects and age-matched control subjects. Circles and triangles show transcription levels of each subject; these are represented by $1 / \Delta \mathrm{Ct}$. Statistical analysis through the Mann-Whitney test.

\subsection{Expression Levels of TRIM28 Following Therapy with DAAs}

No significant variations of TRIM28 were observed in subjects who underwent sofosbuvir/ ledipasvir therapy: $0.278+/-0.032$ at time $0,0.296+/-0.030$ at time $1,0.316+/-0.086$ at time 3, and $0.290+/-0.039$ at time 6 (Figure 4 ).

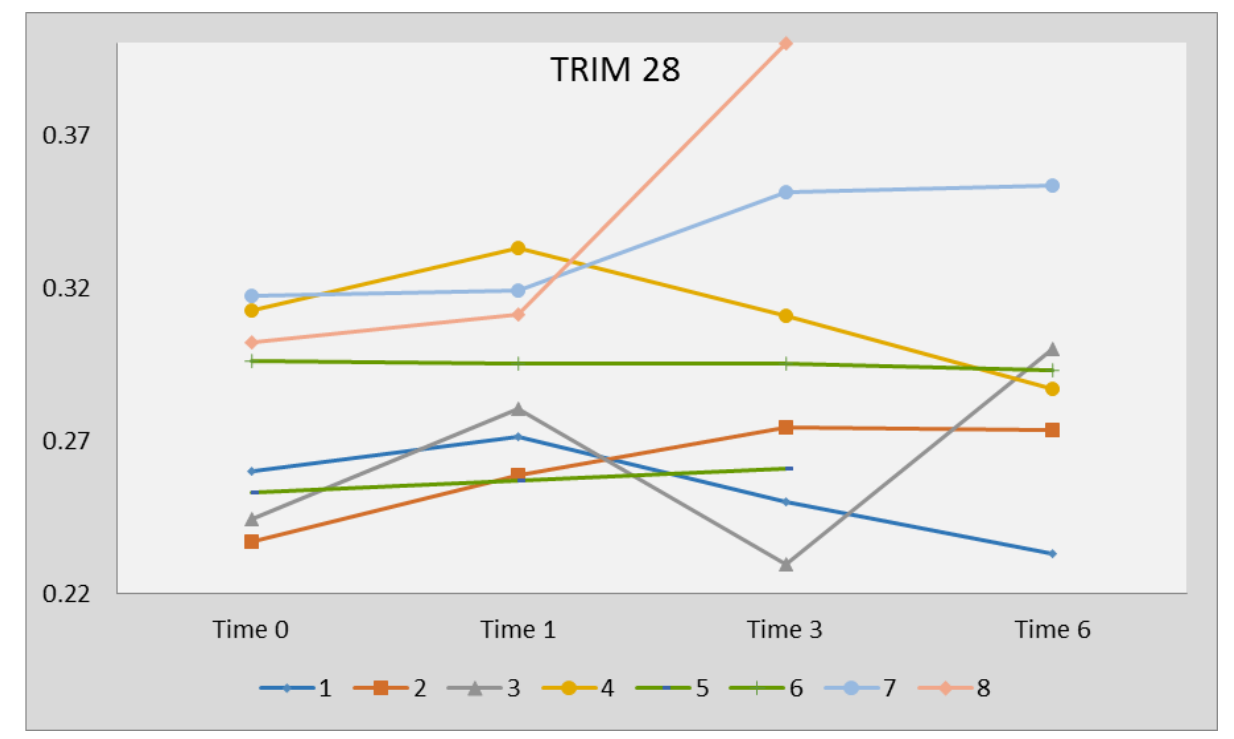

Figure 4. Transcription levels of TRIM28 in WBCs from HCV-infected adolescents before (time 0), after 1 month (time 1), and at suspension (time 3) of sofosbuvir/ledipasvir therapy, and 3 months later. Transcription levels are represented by $1 / \Delta \mathrm{Ct}$. Statistical analysis through two-way ANOVA test: $p=0.7882$.

\section{Discussion}

The results of our study show, for the first time, that HCV RNA+ children and adolescents with vertically acquired infection have significantly higher transcription levels of the pol genes of HERV-H and HERV-K in WBCs as compared to an age-matched control group. HERV-H-pol and HERV-K-pol overexpression remained unchanged during therapy and after DAA-induced viral clearance and was 
not attributable to reduced transcription of the TRIM28 repressor. In contrast, no dysregulation of HERV-W-pol RNA was observed between HCV-infected subjects and the control group.

The origin of enhanced HERV-H-pol and HERV-K-pol RNAs in subjects with chronic HCV infection remains to be elucidated. Several viral infections, such as herpesviruses [21-23], HIV [24] and influenza [25], can cause transactivation of retroviral sequences. Exogenous viral infections produce proinflammatory cytokines and type 1 interferons that lead to an independent and synergistic upregulation of endogenous retroviruses [26]. In particular, $\mathrm{HCV}$ infection triggers an inflammatory response via TLR/NF-kB pathway [27]. After nuclear translocation, the active isoform of NF-kB binds to specific sequences of HERV proviruses, and, with proinflammatory cytokines [26], it may give rise to the greater transcription of pol genes of HERV-H and $-\mathrm{K}$ found in our patients. In contrast, HERVW-pol sequences could be less responsive. HERV activation enhances the cell resistance to secondary infections through stimulation of innate immunity [28], but it exposes the cell to the potential negative impact of HERVs on the gene regulatory network and on physiological functions. In fact, endogenous retroviruses may enhance or suppress the transcription of adjacent cellular genes; through a copy and paste mechanism they may give rise to novel insertions into the DNA, and their RNAs, being sensed as nonself by PRR, can elicit inflammatory and immune reactions [12,29].

HERVs are tightly repressed transcriptionally by host TRIM28 $[19,20]$. This is an E3 ligase that mediates the transfer of ubiquitin or the small ubiquitin-like modifier (SUMO) to target substrates [30]. Among the virus-driven mechanisms responsible for HERV activation, it has been shown that influenza A virus elicits a SUMO-mediated metabolic switch with the modification status of TRIM28, resulting in the derepression of retroviral elements [25]. TRIM28 expression levels were higher, although without a statistically significant difference, in $\mathrm{HCV}$-infected patients as compared to the control group and remained unchanged after DAA treatment. Therefore, the increased quantities of HERV-H-pol and HERV-K-pol RNAs observed in our patients cannot be ascribed to impaired transcription of TRIM28 repressor.

An intriguing aspect of our findings was that HERV-H-pol and HERV-K-pol transcripts did not change after DAA-induced viral clearance. This might be due to the fact that the HCV was not completely eliminated by treatment: an occult infection has actually been detected in WBCs from subjects with a positive response to DAA [31,32]. However, an indelible imprinting of HCV on activation of HERV sequences cannot be excluded.

Independently of the underlying mechanism(s), the upregulation of HERV-H and HERV-K in HCV-infected subjects might explain their high risk of cancers and autoimmune disorders [1-5] that persist after drug-driven viral clearance $[6,7,10,11]$. HERV-H is the most represented retroviral family in the human genome [33]. High levels of its fragments were detected in several cancer cells $[16,34,35]$ representing a critical determinant of tumor progression and immune escape [36,37]. HERV-K is a recently acquired retroviral family, with formation into the human genome of specific sequences not present in other primates [38,39]. It has been widely studied and proposed as directly involved in carcinogenesis, tumor progression [39-43], and drug resistance [44]. HERV-K accessory proteins, such as Np9 and Rec, are putative potent oncogenes [38] and a few envelope proteins may facilitate cell transformation and metastasis [45]. It must be underlined that HERV-K upregulation has been found in patients with lymphoma [46] and HCC [47], typical tumors of HCV-infected subjects. Notably, the increase in HERV-K expression was significantly related not only to cancer evolution but also to development of cirrhosis [47]. On this basis, our results suggest that retroviral elements could also influence the HCV progression towards cirrhosis. The vicious circle: HCV-induced inflammation -> enhanced HERV transcription mediated by NF-kB/inflammatory cytokines -> HERV RNAs sensed as nonself by PRRs -> further inflammation may lead to progressive liver damage and reparatory fibrosis.

Besides its impact on cirrhosis and carcinogenesis, HERV activation may lead to alterations in the host immune system with autoimmune reactions like those observed in children with vertically acquired HCV infection [8,9]. An increasing number of clinical and experimental findings [17,18], including targeted research in animals [48-50], support the potential etiopathogenetic role of HERVs 
in triggering and/or maintaining autoimmune diseases [51]. Some retroviral epitopes can share molecular mimicry with components of body tissues or exogenous viruses. HERV-encoded proteins are targets of autoreactivity in patients with SLE [52]. Higher quantities of surface HERV-H env proteins have been found in leucocytes of patients with active multiple sclerosis, accompanied by increased specific seroreactivity [53]. A significant upregulation in HERV-K mRNA concentrations, [54] and elevated antibody response to a HERV-K-gag [55] and env [56] peptides, were found in subjects with rheumatoid arthritis, while a HERV-K superantigen was detected in those with juvenile arthritis [57]. Therefore, higher HERV expression in subjects with chronic HCV infection might justify their risk of developing malignancies and/or autoimmune disorders persisting after DAA-induced resolution of viremia. However, whether endogenous retroviruses really play a crucial pathogenetic role in these pathologies or just represent a secondary epiphenomenon remains questionable.

Some limits and doubts arise from our study. The primers and probes we used encompass all pol genes of HERV-H and HERV-K; therefore, no specific sequences could be identified and, thus, no possibility to associate a specific locus with a defined molecular pathogenetic mechanism. Furthermore, we did not assess their protein-coding capacity, even though HERVs, as noncoding regulatory elements, can induce or block the activity of neighboring cellular genes and their transcripts may be recognized as nonself by viral RNA receptors [29] with consequent alterations in the cellular homeostasis. Whereas a few children developed autoimmune phenomena, none had cirrhosis or cancers, which presumably require longer incubation periods. Consequently, the overexpression of HERVs found in patients with cirrhosis and HCC [47] needs to be confirmed in subjects with prolonged drug-driven viral clearance, to further support their putative role in these pathologies.

In conclusion, despite the small sample size, our study is the first to provide insights into the enhanced expression of some HERVs in HCV-infected subjects that does not fade after DAA-induced viral clearance. This durable activation of retroviral sequences might account for some HCV-related complications, such as the development of cancers and autoimmune diseases, that persist after the resolution of viremia. Targeted studies on larger study populations and sustained viral clearance are needed to shed further light on this intriguing aspect that can open new prophylactic and therapeutic strategies to avoid some complications linked to HCV infection.

\section{Materials and Methods}

\subsection{Study Populations}

HCV RNA+ children and adolescents with vertically acquired infection were studied. Of these, those older than 12 years underwent treatment with sofosbuvir/ledipasvir according to a national protocol [58]; the latter were tested before (time 0 ), after 1 month (time 1), and at suspension (time 3) of 3 months of therapy, and 3 months later (time 6).

Asymptomatic subjects of comparable age who were tested at the Regina Margherita Children's Hospital, Turin, Italy, for routine laboratory examinations, and whose results were all within the normal reference range, were the control group. Subjects with any confirmed or suspected disease, such as infections, cancer, autoimmune disorders, inflammatory diseases, neurological disturbances, or abnormal laboratory results, were excluded from the study. The tests were performed using leftovers of laboratory samples; data were gathered anonymously.

\subsection{Detection of HCV RNA}

HCV RNA was detected by a real-time PCR assay (Cobas AmpliPrep/Cobas TaqMan HCV, Roche, Basel, Switzerland).

\subsection{Total RNA Extraction and Retro-Transcription}

Total RNA was extracted from WBCs using the automated extractor Maxwell (Promega, Madison, WI, USA) following the RNA Blood Kit protocol without modification. This kit provides treatment 
with DNase during the RNA extraction process. Four hundred nanograms of total RNA was reverse-transcribed with $2 \mu \mathrm{L}$ of buffer $10 \mathrm{X}, 4.8 \mu \mathrm{L}$ of $\mathrm{MgCl}_{2} 25 \mathrm{mM}, 2 \mu \mathrm{L}$ ImpromII (Promega), $1 \mu \mathrm{L}$ of RNase inhibitor $20 \mathrm{U} / \mathrm{L}, 0.4 \mu \mathrm{L}$ random hexamers $250 \mu \mathrm{M}$ (Promega), $2 \mu \mathrm{L}$ mix dNTPs $100 \mathrm{mM}$ (Promega), and dd-water in a final volume of $20 \mu \mathrm{L}$. The reaction mix was carried out in a GeneAmp PCR system 9700 Thermal Cycle (Applied Biosystems, Foster City, CA, USA) under the following conditions: $5 \mathrm{~min}$ at $25^{\circ} \mathrm{C}, 60 \mathrm{~min}$ at $42{ }^{\circ} \mathrm{C}$, and $15 \mathrm{~min}$ at $70{ }^{\circ} \mathrm{C}$ for the inactivation of enzyme; the cDNAs were stored at $-80^{\circ} \mathrm{C}$ until use. For control of genomic DNA contamination, we amplified RNA extracts directly without reverse transcription.

\subsection{Transcription Levels of Pol Genes of HERV-H, HERV-K, HERV-W and of TRIM28}

Relative quantification of mRNA expression of HERV-H, $-\mathrm{K}-\mathrm{W}$ and of TRIM28 was achieved by means of PCR real-time TaqMan amplification and normalization to glyceraldehyde-3-phosphate dehydrogenase (GAPDH) using the ABI PRISM 7500 real-time system (Life technologies, Carlsbad, CA, USA). GAPDH was chosen as the reference gene, being the most stable among 9 reference genes [59] and previously used in our studies [43,60-62]. A 40-ng quantity of cDNA was amplified using HERV-H, $-\mathrm{K}-\mathrm{W}$, and TRIM28 gene mRNA expression kit PP-BioMole-054, -055, -056, and 044 respectively (BioMole srl, Turin, Italy) in a $20 \mu \mathrm{L}$ total volume reaction.

The amplifications were run in a 96-well plate at $95^{\circ} \mathrm{C}$ for $10 \mathrm{~min}$, followed by 40 cycles at $95^{\circ} \mathrm{C}$ for $15 \mathrm{~s}$, and at $60^{\circ} \mathrm{C}$ for $1 \mathrm{~min}$. Furthermore, in order to confirm that there was no DNA genomic contamination, control PCR was performed with RNA before reverse transcription, using the same primers and probes described above. Each sample was run in triplicate. Relative quantification of target gene expression was performed with the $\Delta \mathrm{Ct}$ method. Using $40 \mathrm{ng}$ of cDNA in amplification, we obtained $\mathrm{Ct}$ values from 26 to 30.4. These $\mathrm{Ct}$ values correspond to a good performance of real-time PCR. Since we measured Ct for every target in all the samples tested, we argued that our methods were suitable for HERV detection and quantification. Results were expressed as $1 / \Delta \mathrm{Ct}$.

\subsection{Statistical Analysis}

The Mann-Whitney test was used to compare the transcriptional levels of pol genes of every HERV family as well as of TRIM28 in WBCs from HCV-infected subjects vs. age-matched controls. A two-way ANOVA test was used to compare the transcriptional levels of each HERV group before (time 0 ), after 1 month (time 1), and at suspension (time 3) of sofosbuvir/ledipasvir therapy, and 3 months later (time 6). Statistical analyses were done using the Prism software (GraphPad Software, La Jolla, CA, USA). In all analyses, $p<0.05$ was taken to be statistically significant.

Clinical data were treated in accordance with the principles of Helsinki Declaration (World Medical Association General Assembly, Seoul, Korea, October 2008). The study protocol was approved by AIFA (24.04.2018) and Azienda Ospedaliera-Universitaria Città della Salute e della Scienza, Turin (final amendment 20.04.2020); code 289571.

Author Contributions: P.-A.T., substantial contributions to the conception of the work; drafting the work, revising it critically for important intellectual contents and its final approval; S.G., enrollment and follow-up of patients, drafting the work, revising it critically for important intellectual content and final approval; E.S., enrollment and follow-up of patients, final revision of the manuscript; V.D., I.G., C.C., C.A., P.M., performed laboratory tests, substantial contributions to analysis and interpretation of data; M.B., substantial contributions to the conception or design of the work and the acquisition, analysis, and interpretation of data. All authors have read and agreed to the published version of the manuscript.

Funding: This research received no external funding.

Conflicts of Interest: The authors declare no conflict of interest. 


\section{Abbreviations}

$\begin{array}{ll}\text { ANA } & \text { Anti-nuclear antibodies } \\ \text { DAAs } & \text { Direct-acting antivirals } \\ \text { GAPHD } & \text { Glyceraldehyde-3-phosphate dehydrogenase } \\ \text { HCC } & \text { Hepatocellular carcinoma } \\ \text { HCV } & \text { Hepatis C virus } \\ \text { HERVs } & \text { Human endogenous retroviruses } \\ \text { LKM-1 } & \text { Liver and kidney microsomal type 1 } \\ \text { NF-kB } & \text { Nuclear factor kB } \\ \text { PCR } & \text { Polymerase chain reaction } \\ \text { PRRs } & \text { Pattern recognition receptors } \\ \text { SLE } & \text { Systemic lupus erythematous } \\ \text { TLR } & \text { Toll-like receptor } \\ \text { TRIM28 } & \text { Tripartite motif-containing-28 } \\ \text { WBCs } & \text { White blood cells }\end{array}$

\section{References}

1. Negro, F.; Forton, D.; Craxì, A.; Sulkowski, M.S.; Feld, J.J.; Manns, M.P. Extrahepatic morbidity and mortality of chronic hepatitis C. Gastroenterology 2015, 149, 1345-1360. [CrossRef]

2. Su, T.H.; Liu, C.J.; Tseng, T.C.; Chou, S.W.; Liu, C.H.; Yang, H.C.; Wu, S.J.; Chen, P.J.; Chen, D.S.; Chen, C.L.; et al. Hepatitis $C$ viral infection increases the risk of lymphoid-neoplasms: A population-based cohort study. Hepatology 2016, 63, 721-730. [CrossRef] [PubMed]

3. Lee, M.H.; Yang, H.I.; Lu, S.N.; Jen, C.L.; You, S.L.; Wang, L.Y.; Wang, C.H.; Chen, W.J.; Chen, C.J.; R.E.V.E.A.L.-HCV Study Group. Chronic hepatitis C virus infection increases mortality from hepatic and extrahepatic diseases: A community-based long-term prospective study. J. Infect. Dis. 2012, 206, 469-477. [CrossRef] [PubMed]

4. Allison, R.D.; Tong, X.; Moorman, A.C.; Ly, K.N.; Rupp, L.; Xu, F.; Gordon, S.C.; Holmberg, S.D.; Chronic Hepatitis Cohort Study (CHeCS) Investigators. Increased incidence of cancer and cancer-related mortality among persons with chronic hepatitis C infection, 2006-2010. J. Hepatol. 2015, 63, 8. [CrossRef] [PubMed]

5. Obermayer-Straub, P.; Manns, M.P. Hepatitis C and D, retroviruses and autoimmune manifestations. J. Autoimmun. 2001, 16, 275-285. [CrossRef] [PubMed]

6. Chen, C.W.; Cheng, J.S.; Chen, T.D.; Le, P.H.; Ku, H.P.; Chang, M.L. The irreversible HCV-associated risk of gastric cancer following interferon-based therapy: A joint study of hospital-based cases and nationwide population-based cohorts. Therap. Adv. Gastroenterol. 2019, 12, 1756284819855732. [CrossRef] [PubMed]

7. Ioannou, G.N.; Beste, L.A.; Green, P.K.; Singal, A.G.; Tapper, E.B.; Waljee, A.K.; Sterling, R.K.; Feld, J.J.; Kaplan, D.E.; Taddei, T.H.; et al. Increased risk for hepatocellular carcinoma persists up to 10 years after $\mathrm{HCV}$ eradication in patients with baseline cirrhosis or high FIB-4 scores. Gastroenterology 2019. [CrossRef]

8. Garazzino, S.; Calitri, C.; Versace, A.; Alfarano, A.; Scolfaro, C.; Bertaina, C.; Vatrano, S.; Mignone, F.; Licciardi, F.; Gabiano, C.; et al. Natural history of vertically acquired HCV infection and associated autoimmune phenomena. Eur. J. Pediatr. 2014, 173, 1025-1031. [CrossRef]

9. Tovo, P.A.; Calitri, C.; Scolfaro, C.; Gabiano, C.; Garazzino, S. Vertically acquired hepatitis C virus infection: Correlates of transmission and disease progression. World J. Gastroenterol. 2016, 22, 1382-1392. [CrossRef]

10. Bonacci, M.; Lens, S.; Mariño, Z.; Londoño, M.C.; Rodriguez-Tajes, S.; Sánchez-Tapias, J.M.; Ramos-Casals, M.; Hernández-Rodríguez, J.; Forns, X. Long-term outcomes of patients with HCV-associated cryoglobulinemic vasculitis after virologic cure. Gastroenterology 2018, 155, 311-315.e6. [CrossRef]

11. Terziroli Beretta-Piccoli, B.; Di Bartolomeo, C.; Deleonardi, G.; Grondona, A.G.; Silvestri, T.; Tesei, C.; Melidona, L.; Cerny, A.; Mertens, J.; Semmo, N.; et al. Autoimmune liver serology before and after successful treatment of chronic hepatitis C by direct acting antiviral agents. J. Autoimmun. 2019, 102, 89-95. [CrossRef] [PubMed]

12. Johnson, W.E. Origins and evolutionary consequences of ancient endogenous retroviruses. Nat. Rev. Microbiol. 2019, 17, 355-370. [CrossRef] [PubMed] 
13. Sun, Y.; Zhu, H.; Song, J.; Jiang, Y.; Ouyang, H.; Huang, R.; Zhang, G.; Fan, X.; Tao, R.; Jiang, J.; et al. Upregulation of leukocytic syncytin-1 in acute myeloid leukemia patients. Med. Sci. Monit. 2016, 22, 2392-2403. [CrossRef]

14. Liu, C.; Xu, J.; Wen, F.; Yang, F.; Li, X.; Geng, D.; Li, L.; Chen, J.; Zheng, J. Upregulation of syncytin-1 promotes invasion and metastasis by activating epithelial-mesenchymal transition-related pathway in endometrial carcinoma. Onco. Targets Ther. 2019, 12, 31-40. [CrossRef] [PubMed]

15. Katoh, I.; Kurata, S. Association of endogenous retroviruses and long terminal repeats with human disorders. Front. Oncol. 2013, 3, 234. [CrossRef] [PubMed]

16. Zhang, M.; Liang, J.Q.; Zheng, S. Expressional activation and functional roles of human endogenous retroviruses in cancers. Rev. Med. Virol. 2019, 29, e2025. [CrossRef]

17. Yu, P. The potential role of retroviruses in autoimmunity. Immunol. Rev. 2016, 269, 85-99. [CrossRef]

18. Trela, M.; Nelson, P.N.; Rylance, P.B. The role of molecular mimicry and other factors in the association of human endogenous retroviruses and autoimmunity. APMIS 2016, 124, 88-104. [CrossRef]

19. Rowe, H.M.; Jakobsson, J.; Mesnard, D.; Rougemont, J.; Reynard, S.; Aktas, T.; Maillard, P.V.; Layard-Liesching, H.; Verp, S.; Marquis, J.; et al. KAP1 controls endogenous retroviruses in embryonic stem cells. Nature 2010, 463, 237-240. [CrossRef]

20. Turelli, P.; Castro-Diaz, N.; Marzetta, F.; Kapopoulou, A.; Raclot, C.; Duc, J.; Tieng, V.; Quenneville, S.; Trono, D. Interplay of TRIM28 and DNA methylation in controlling human endogenous retroelements. Genome Res. 2014, 24, 1260-1270. [CrossRef]

21. Ruprecht, K.; Obojes, K.; Wengel, V.; Gronen, F.; Kim, K.S.; Perron, H.; Schneider-Schaulies, J.; Rieckmann, P. Regulation of human endogenous retrovirus $W$ protein expression by herpes simplex virus type 1: Implications for multiple sclerosis. J. Neurovirol. 2006, 12, 65-71. [CrossRef] [PubMed]

22. Mameli, G.; Poddighe, L.; Mei, A.; Uleri, E.; Sotgiu, S.; Serra, C.; Manetti, R.; Dolei, A. Expression and activation by Epstein Barr virus of human endogenous retroviruses-W in blood cells and astrocytes: Inference for multiple sclerosis. PLoS ONE 2012, 7, e44991. [CrossRef] [PubMed]

23. Assinger, A.; Yaiw, K.C.; Göttesdorfer, I.; Leib-Mösch, C.; Söderberg-Nauclér, C. Human cytomegalovirus (HCMV) induces human endogenous retrovirus (HERV) transcription. Retrovirology 2013, 10, 132. [CrossRef] [PubMed]

24. van der Kuyl, A.C. HIV infection and HERV expression: A review. Retrovirology 2012, 9, 6. [CrossRef]

25. Schmidt, N.; Domingues, P.; Golebiowski, F.; Patzina, C.; Tatham, M.H.; Hay, R.T.; Hale, B.G. An influenza virus-triggered SUMO switch orchestrates co-opted endogenous retroviruses to stimulate host antiviral immunity. Proc. Natl. Acad. Sci. USA 2019, 116, 17399-17408. [CrossRef]

26. Manghera, M.; Ferguson-Parry, J.; Lin, R.; Douville, R.N. NF- $k B$ and IRF1 induce endogenous retrovirus K expression via interferon-stimulated response elements in its 5' long terminal repeat. J. Virol. 2016, 90, 9338-9349. [CrossRef]

27. Rajalakshmy, A.R.; Malathi, J.; Madhavan, H.N. Hepatitis C Virus NS3 mediated microglial inflammation via TLR2/TLR6 MyD88/NF-KB pathway and toll like receptor ligand treatment furnished immune tolerance. PLoS ONE 2015, 10, e0125419. [CrossRef]

28. Rolland, A.; Jouvin-Marche, E.; Viret, C.; Faure, M.; Perron, H.; Marche, P.N. The envelope protein of a human endogenous retrovirus-W family activates innate immunity through CD14/TLR4 and promotes Th1-like responses. J. Immunol. 2006, 176, 7636-7644. [CrossRef]

29. Mu, X.; Ahmad, S.; Hur, S. Endogenous retroelements and the host innate immune sensors. Adv. Immunol. 2016, 132, 47-69.

30. Deshaies, R.J.; Joazeiro, C.A. RING domain E3 ubiquitin ligases. Annu. Rev. Biochem. 2009, 78, $399-434$. [CrossRef]

31. Pham, T.N.; Mulrooney-Cousins, P.M.; Mercer, S.E.; MacParland, S.A.; Inglot, M.; Zalewska, M.; Simon, K.; Michalak, T.I. Antagonistic expression of hepatitis $C$ virus and alpha interferon in lymphoid cells during persistent occult infection. J. Viral. Hepat. 2007, 14, 537-548. [CrossRef] [PubMed]

32. Austria, A.; Wu, G.Y. Occult Hepatitis C virus infection: A Review. J. Clin. Transl. Hepatol. 2018, 6, 155-160. [CrossRef] [PubMed]

33. Jern, P.; Sperber, G.O.; Blomberg, J. Definition and variation of human endogenous retrovirus H. Virology 2004, 327, 93-110. [CrossRef] [PubMed] 
34. Yi, J.M.; Kim, H.M.; Kim, H.S. Human endogenous retrovirus HERV-H family in human tissues and cancer cells: Expression, identification, and phylogeny. Cancer Lett. 2006, 23, 228-239. [CrossRef] [PubMed]

35. Wentzensen, N.; Coy, J.F.; Knaebel, H.P.; Linnebacher, M.; Wilz, B.; Gebert, J.; von Knebel Doeberitz, M. Expression of an endogenous retroviral sequence from the HERV-H group in gastrointestinal cancers. Int. J. Cancer 2007, 121, 1417-1423. [CrossRef] [PubMed]

36. Reis, B.S.; Jungbluth, A.A.; Frosina, D.; Holz, M.; Ritter, E.; Nakayama, E.; Ishida, T.; Obata, Y.; Carver, B.; Scher, H.; et al. Prostate cancer progression correlates with increased humoral immune response to a human endogenous retrovirus GAG protein. Clin. Cancer Res. 2013, 19, 6112-6125. [CrossRef]

37. Kudo-Saito, C.; Yura, M.; Yamamoto, R.; Kawakami, Y. Induction of immunoregulatory CD271+ cells by metastatic tumor cells that express human endogenous retrovirus H. Cancer Res. 2014, 74, 1361-1370. [CrossRef]

38. Subramanian, R.P.; Wildschutte, J.H.; Russo, C.; Coffin, J.M. Identification, characterization, and comparative genomic distribution of the HERV-K (HML-2) group of human endogenous retroviruses. Retrovirology 2011, 8, 90. [CrossRef]

39. Grandi, N.; Tramontano, E. Human endogenous retroviruses are ancient acquired elements still shaping innate immune responses. Front. Immunol. 2018, 9, 2039. [CrossRef]

40. Oricchio, E.; Sciamanna, I.; Beraldi, R.; Tolstonog, G.V.; Schumann, G.G.; Spadafora, C. Distinct roles for LINE-1 and HERV-K retroelements in cell proliferation, differentiation and tumor progression. Oncogene 2007, 26, 4226-4233. [CrossRef]

41. Serafino, A.; Balestrieri, E.; Pierimarchi, P.; Matteucci, C.; Moroni, G.; Oricchio, E.; Rasi, G.; Mastino, A.; Spadafora, C.; Garaci, E.; et al. The activation of human endogenous retrovirus K (HERV-K) is implicated in melanoma cell malignant transformation. Exp. Cell. Res. 2009, 315, 849-862. [CrossRef] [PubMed]

42. Li, M.; Radvanyi, L.; Yin, B.; Rycaj, K.; Li, J.; Chivukula, R.; Lin, K.; Lu, Y.; Shen, J.; Chang, D.Z.; et al. Downregulation of human endogenous retrovirus type K (HERV-K) viral env RNA in pancreatic cancer cells decreases cell proliferation and tumor growth. Clin. Cancer Res. 2017, 23, 5892-5911. [CrossRef] [PubMed]

43. Bergallo, M.; Montanari, P.; Mareschi, K.; Merlino, C.; Berger, M.; Bini, I.; Daprà, V.; Galliano, I.; Fagioli, F. Expression of the pol gene of human endogenous retroviruses HERV-K and $-\mathrm{W}$ in leukemia patients. Arch. Virol. 2017, 162, 3639-3644. [CrossRef] [PubMed]

44. Iramaneerat, K.; Rattanatunyong, P.; Khemapech, N.; Triratanachat, S.; Mutirangura, A. HERV-K hypomethylation in ovarian clear cell carcinoma is associated with a poor prognosis and platinum resistance. Int. J. Gynecol. Cancer 2011, 21, 51-57. [CrossRef]

45. Zhou, F.; Li, M.; Wei, Y.; Lin, K.; Lu, Y.; Shen, J.; Johanning, G.L.; Wang-Johanning, F. Activation of HERV-K Env protein is essential for tumorigenesis and metastasis of breast cancer cells. Oncotarget 2016, 7, 84093-84117. [CrossRef]

46. Gitlin, S.D.; Contreras-Galindo, R.; Kaplan, M.H.; Markovitz, D.M. Role of human endogenous retroviruses in lymphoma pathogenesis and a possible biomarker of disease. Blood 2008, 112, 1285. [CrossRef]

47. Ma, W.; Hong, Z.; Liu, H.; Chen, X.; Ding, L.; Liu, Z.; Zhou, F.; Yuan, Y. Human endogenous retroviruses-K (HML-2) expression is correlated with prognosis and progress of hepatocellular carcinoma. Biomed. Res. Int. 2016, 2016, 8201642. [CrossRef]

48. Perron, H.; Dougier-Reynaud, H.L.; Lomparski, C.; Popa, I.; Firouzi, R.; Bertrand, J.B.; Marusic, S.; Portoukalian, J.; Jouvin-Marche, E.; Villiers, C.L.; et al. Human endogenous retrovirus protein activates innate immunity and promotes experimental allergic encephalomyelitis in mice. PLoS ONE 2013, 8, e80128. [CrossRef]

49. Ito, K.; Baudino, L.; Kihara, M.; Leroy, V.; Vyse, T.J.; Evans, L.H.; Izui, S. Three Sgp loci act independently as well as synergistically to elevate the expression of specific endogenous retroviruses implicated in murine lupus. J. Autoimmun. 2013, 43, 10-17. [CrossRef]

50. Bashratyan, R.; Regn, D.; Rahman, M.J.; Marquardt, K.; Fink, E.; Hu, W.Y.; Elder, J.H.; Binley, J.; Sherman, L.A.; Dai, Y.D. Type 1 diabetes pathogenesis is modulated by spontaneous autoimmune responses to endogenous retrovirus antigens in NOD mice. Eur. J. Immunol. 2017, 47, 575-584. [CrossRef]

51. Gröger, V.; Cynis, H. Human endogenous retroviruses and their putative role in the development of autoimmune disorders such as multiple sclerosis. Front. Microbiol. 2018, 9, 265. [CrossRef] [PubMed] 
52. Perl, A.; Nagy, G.; Koncz, A.; Gergely, P.; Fernandez, D.; Doherty, E.; Telarico, T.; Bonilla, E.; Phillips, P.E. Molecular mimicry and immunomodulation by the HRES-1 endogenous retrovirus in SLE. Autoimmunity 2008, 41, 287-297. [CrossRef] [PubMed]

53. Brudek, T.; Christensen, T.; Aagaard, L.; Petersen, T.; Hansen, H.J.; Møller-Larsen, A. B cells and monocytes from patients with active multiple sclerosis exhibit increased surface expression of both HERV-H Env and HERV-W Env, accompanied by increased seroreactivity. Retrovirology 2009, 6, 104. [CrossRef] [PubMed]

54. Freimanis, G.; Hooley, P.; Ejtehadi, H.D.; Ali, H.A.; Veitch, A.; Rylance, P.B.; Alawi, A.; Axford, J.; Nevill, A.; Murray, P.G. A role for human endogenous retrovirus-K (HML-2) in rheumatoid arthritis: Investigating mechanisms of pathogenesis. Clin. Exp. Immunol. 2010, 160, 340-347. [CrossRef]

55. Nelson, P.N.; Roden, D.; Nevill, A.; Freimanis, G.L.; Trela, M.; Ejtehadi, H.D.; Bowman, S.; Axford, J.; Veitch, A.M.; Tugnet, N.; et al. Rheumatoid arthritis is associated with IgG antibodies to human endogenous retrovirus gag matrix: A potential pathogenic mechanism of disease? J. Rheumatol. 2014, 41, 1952-1960. [CrossRef]

56. Mameli, G.; Erre, G.L.; Caggiu, E.; Mura, S.; Cossu, D.; Bo, M.; Cadoni, M.L.; Piras, A.; Mundula, N.; Colombo, E.; et al. Identification of a HERV-K env surface peptide highly recognized in rheumatoid arthritis (RA) patients: A cross-sectional case-control study. Clin. Exp. Immunol. 2017, 189, 127-131. [CrossRef]

57. Sicat, J.; Sutkowski, N.; Huber, B.T. Expression of human endogenous retrovirus HERV-K18 superantigen is elevated in juvenile rheumatoid arthritis. J. Rheumatol. 2005, 32, 1821-1831.

58. Indolfi, G.; Easterbrook, P.; Dusheiko, G.; Siberry, G.; Chang, M.H.; Thorne, C.; Bulterys, M.; Chan, P.L.; El-Sayed, M.H.; Giaquinto, C.; et al. Hepatitis C virus infection in children and adolescents. Lancet Gastroent. Hepatol. 2019, 4, 477-487. [CrossRef]

59. Garson, J.A.; Usher, L.; Al-Chalabi, A.; Huggett, J.; Day, E.F.; McCormick, A.L. Quantitative analysis of human endogenous retrovirus-K transcripts in postmortem premotor cortex fails to confirm elevated expression of HERV-K RNA in amyotrophic lateral sclerosis. Acta Neuropathol. Commun. 2019, 7, 102. [CrossRef]

60. Bergallo, M.; Galliano, I.; Pirra, A.; Daprà, V.; Licciardi, F.; Montanari, P.; Coscia, A.; Bertino, E.; Tovo, P.A. Transcriptional activity of human endogenous retroviruses is higher at birth in inversed correlation with gestational age. Infect. Genet. Evol. 2019, 68, 273-279. [CrossRef]

61. Bergallo, M.; Galliano, I.; Daprà, V.; Pirra, A.; Montanari, P.; Pavan, M.; Calvi, C.; Bertino, E.; Coscia, A.; Tovo, P.A. Transcriptional activity of human endogenous retroviruses in response to prenatal exposure of maternal cigarette smoking. Am. J. Perinatol. 2019, 36, 1060-1065. [CrossRef] [PubMed]

62. Bergallo, M.; Marozio, L.; Botta, G.; Tancredi, A.; Daprà, V.; Galliano, I.; Montanari, P.; Coscia, A.; Benedetto, C.; Tovo, P.A. Human endogenous retroviruses are preferentially expressed in mononuclear cells from cord blood than from maternal blood and in the fetal part of placenta. Front. Pediatr. 2020, 8, 244. [CrossRef] 